\title{
Medical gels and the risk of serious infection
}

Reason for posting: Gels are routinely used in a variety of physical examination and diagnostic medical procedures including ultrasonography and endoscopy. Health Canada, however, has recently warned that several common practices involving the gels may lead to infection. ${ }^{1}$ These practices include warming the gels in uncapped containers for extended periods of time, not cleaning refillable squeeze bottles, and using nonsterile gels marked for external use only during invasive procedures (such as biopsies) or on mucous membranes. Although no cases of infection linked to these practices are reported in the Health Canada letter, several cases exist in the medical literature of nosocomial infections traced back to contaminated ultrasound gels. ${ }^{2-4}$

What to do: Health Canada has issued recommendations for minimizing the health risks of using gels (see Box 1). In combination with the use of disposable barriers (such as a surgical glove, condom, household cling film or sterile "Opsite" films) ${ }^{4}$ placed on nonsterile ultrasound probes,

\& these recommendations appear $\exists$ to represent common sense infection control precautions that ․․․ are easy to implement in both î̀ hospital and community settings.

Box 1: Recommended practices for minimizing the risk of serious infection from ultrasound and medical gels*

Sterile gels should be used:

- for invasive procedures that pass a device through a tissue (e.g., needle biopsies)

- for all procedures involving sterile equipment or non-intact skin

- on neonates

- for procedures on intact mucous membranes (e.g., esophageal, gastric, rectal, vaginal)

Nonsterile gels:

- single-use containers should be used

- if using refillable containers, they should not be "topped up" but must be emptied, washed in hot soapy water with hospital grade disinfectant, rinsed thoroughly and dried before refilling

- cracked reusable containers should be discarded

- expiration dates on bulk containers need to be carefully monitored

- gels should not be aspirated from the bulk gel containers (which can contaminate the bulk container) but dispensed from bulk containers into reuseable containers

- tips of dispensing containers should not come into contact with patients, staff, instruments or the environment (dispense the gel into a cup or onto a disposable cloth, or at least wipe the dispensing nozzle with a clean alcohol swab between patients)

Warming the gel:

- warm the gel only when it is needed

- remove bottles from the warmer as soon as possible and dry them immediately

- clean the warmers weekly with a low-level hospital grade disinfectant

*Adapted and abbreviated from reference 1.

\section{References}

1. Health Canada. Notice to hospitals: important safety information on ultrasound and medical gels. 2004 October 20. Available: www.hc-sc.gc.ca/hpfbdgpsa/tpd-dpt/ultrasoundgel_e.html (accessed 2004 Oct 27).

2. Hutchinson J, Runge W, Mulvey M, Norris G, Yetman M, Valkova N, et al. Burkbolderia cepacia infections associated with intrinsically contaminated ultrasound gel: the role of microbial degradation of parabens. Infect Control
Hosp Epidemiol 2004:25(4):291-6.

3. Weist K, Wendt C, Petersen LR, Versmold H, Ruden H. An outbreak of pyodermas among neonates caused by ultrasound gel contaminated with methicillin-susceptible Staphylococcus aureus. Infec Control Hosp Epidemiol 2000;21(12):761-4.

4. Abdullah BJ, Mohd Yusof MY, Khoo $\mathrm{BH}$. Physical methods of reducing the transmission of nosocomial infections via ultrasound and probe. Clin Radiol 1998;53(3):212-4.

\section{Canadian Adverse Reaction Newsletter Bulletin canadien des effets indésirables \\ To receive the Newsletter and health product Advisories by email, join Health Canada's Health_Prod_Info mailing list. Go to www.hc-sc.gc.calhpfb-dgpsaltpd-dpt/subscribe_e.html. \\ Inscrivez-vous à la liste Info_Prod_Santé de Santé Canada pour recevoir par courriel le Bulletin et les Avis au sujet des produits de santé. Rendez-vous à l'adresse www.hc-sc.gc.calhpfb-dgpsaltpd-dpt/subscribe f.html. \\ Report adverse reactions toll free to Health Canada Signaler sans frais des effets indésirables à Santé Canada \\ Tel./Tél. : 866 234-2345• Fax/Téléc. : 866 678-6789

